\title{
Analysis of Misunderstanding Caused by Different Interpretations of Speech Act Labels in Tintin and Asterix Comic Series
}

\author{
Farah Attamimi \\ English Department, Faculty of Letters, Maranatha Christian University, \\ Suria Sumantri 65, Bandung 40164, Indonesia \\ e-mail: farah.attamimi@yahoo.com
}

\begin{abstract}
This paper presents analysis of misunderstanding occurred in a conversation which is caused by different interpretation of speech act labels between the speaker and the hearer. Misunderstanding occurred in these comic series causes various emotional effects to the hearer involved in the conversation. The hearer might feel happy, impressed, embarrassed, or even proud of what the speaker conveys through his/ her utterance. It depends on the face wants used and intended between the participants in the conversation. According to Goffman in Brown and Levinson (1987), "face is something that is emotionally invested, and that can be lost, maintained, or enhanced, and must be constantly attended to in interaction" (p. 60). There are two kinds of face wants. The positive purpose is called face saving act, while the negative one is called face threatening act. The data in this paper are taken from Tintin and Asterix comic series. The theories used cover pragmatics area, especially taxonomy of speech act theory (Yule, 1996; Mey, 2001; Leech, 1991) and theory of the notion of face by Erving Goffman (as cited in Yule, 1996; Thomas, 1995). Therefore, this paper will try to convey how the misinterpretation of speech act labels affects the participants in the conversation.
\end{abstract}

Key words: misunderstanding, speech act labels, speaker, hearer, face wants, face saving act, face threatening act, participants

Language is one of the most important aspects in building communication. According to Nasr (as cited in Sukarno, 2010), "languages are said to be unique” (p. 59). Without language, both the verbal and non verbal language, people will not be able to communicate well. Levinson (1995) states that "communication is a complex kind of intention that is achieved or satisfied just by being recognized" (p. 16). However, as an 
utterance conveyed by a speaker may be interpreted as many more than one meaning by a hearer, even with the existence of language, misinterpretation may happen. Levinson defines an utterance as "the issuance of a sentence, a sentence-analogue, or sentence-fragment, in an actual context” (p. 18). A good communication, of course, needs to be supported by the use of appropriate language in one circumstance with the intention of conveying the correct information or messages to the other participants, so as to avoid misinterpretation. Crowley \& Mitchell (as cited in Tupan \& Natalia, 2008), support the above explanation that "in a conversation, a speaker and a hearer are supposed to respond to each other in their turn and exchange with the needed information that benefits both of them” (p. 63).

The subject of misunderstanding is interesting to discuss because it is something that commonly happens, regardless of time, place and participants of the conversation. In addition, it gives the writer such a big curiosity to find out some factors affecting misunderstanding and the various emotional effects on the participants appearing in a certain conversation.

One of the factors that cause misinterpretation in human communication is the different interpretation of speech act labels. The same words can be used to perform different speech act; therefore, different words can be used to perform the same speech act (as cited in Thomas, 1995, p. 51). One utterance which is labelled a question by a speaker may be interpreted differently by a hearer. For instance, the hearer may interpret it as an insult. As a result, this misinterpretation may cause him or her to feel offended. In association with the above opinion, Grundy (2000) adds that "a sentence with interrogative form can be taken not only as a question, but also as an indirect request/ order or as an indirect assertions" (p. 58).

The writer chooses Tintin and Asterix comic series as the data source because it is popular not only with children, but also with adults. In those comic series, the writer can find a lot of amusingly funny scenes and they are often caused by some elements of misunderstanding in the characters' interactions.

Tintin is one of the most famous comic series in the world. It was first printed in 1930. Asterix is a fictional character, created in $\underline{1959}$ as the hero of a French comic series. Both Tintin and Asterix have a very good story. 
The story is a combination of a thriller, adventure and comedy which usually takes place in many countries.

In this analysis, there are two theories in Pragmatics that are used as the approaches. Yule (1996) points out that "pragmatics is concerned with the study of meaning as communicated by a speaker and interpreted by a listener. It has, consequently, more to do with the analysis of what people mean by their utterances than what the words or phrases in those utterances might mean by themselves” (p. 3). In line with Yule's explanation about Pragmatics, Johnson and Johnson (as quoted in Al-Marrani, 2010) state that "pragmatic competence is an aspect of communicative competence and refers to the ability to communicate appropriately in particular context of use" (p. 63). Thomas (as cited in Kusumarasdyati, 2003) also emphasizes that "pragmatics recognizes the importance of context, and thus can reveal the meaning underlying a certain utterance” (p. 14).

In this area, the writer applies the speech act theory by John Searle, an American philosopher. Searle presents a rational taxonomy of types of speech act; besides, he explores the relation between the meaning of sentences and the contexts of their utterances. (Yule, 1996; Mey, 2001)

The second theory applied is Erving Goffman's theory of the notion of face, which is closely connected politeness area (Yule, 1996; Thomas 1995). Goffman is a well-known sociologist who provides a description of how language is positioned in particular circumstances of social life, and how it reflects, and adds meaning and structure in those circumstances. By applying the theory of the notion of face, we may discover that misunderstanding will cause the different emotional reaction of face saving and face threatening acts between the participants. Goffman considers emotions and feelings such as embarrassment, shame, pride, and he makes these an integral part of his analysis of social face.

There are several problems that would be discussed in this paper: 1) Which Speech Act labels are misinterpreted in the conversation in 'Tintin' and 'Asterix' comic series? 2) How are the Speech Act labels misinterpreted? 3) What is the effect of each misinterpretation in the conversation on the participants?

The contributions of the present study are to show: 1) The Speech Act labels which are misinterpreted in the conversation in 'Tintin' and 'Asterix' comic series. 2) How the Speech Act labels are misinterpreted. 3) The effect of each misinterpretation in the conversation on the participants. 


\section{SPEECH ACT}

In expressing something, people do not only produce utterances containing grammatical structures and words, they also perform actions via those utterances. According to Yule (1996), "actions performed via utterances are generally called speech acts” (p. 47). In line with the definition, Mey (2001) also states that speech acts are "words with which to do things" (p. 93). As mentioned before, in English, speech acts are usually given more specific labels such as apology, complaint, order, invitation, promise, request, etc.

Austin (as cited in Thomas, 1995) states that he used the term speech act to refer to "an utterance and the total situation in which the utterance is issued” (p. 51). Austin's ideas about speech acts are elaborated by John Searle, an American philosopher. It is said in Schiffrin (1994) that Searle focuses his works on the classification of acts about which people know and the way that a single utterance can be associated with more than one act.

Searle proposes one general classification system listing five types of general functions performed by speech acts (Yule, 1996; Mey, 2001; Leech, 1991). They are:

1. Declarations: "those kinds of speech acts that change the world via their utterance” (Yule, 1996, p. 53). e.g, appointing, marrying, excommunicating, declaring war, christening, dismissing, resigning, sentencing, etc. In order to perform this speech act appropriately, the speaker has to have a special institutional role, in a specific context. (Yule, 1996; Leech, 1991)

2. Representatives/ Assertive: "those kinds of speech acts that state what the speaker believes to be the case or not" (Yule, 1996, p. 53). e.g, statement of facts, insistence, asserting, concluding, boasting, describing, claiming, reporting, complaining, etc.

3. Expressives: "those kinds of speech acts that state what the speaker feels. They express a psychological state and can be statements of pleasure, pain, likes, dislikes, joy, or sorrow” (p. 53). e.g, thanking, apologizing, welcoming, insulting, congratulating, accusing, blaming, praising, condoling, etc.

4. Directives: "those kinds of speech acts that speakers use to get someone else to do something. They express what the speaker wants. They can be positive or negative” (p. 54). e.g, commanding, ordering, requesting, suggesting, challenging, daring, asking, begging, dismissing, excusing, 
forbidding, warning, instructing, permitting, requiring, recommending, etc.

5. Commissives: "those kinds of speech acts that speakers use to commit themselves to some future action. They express what the speaker intends to do. They can be performed by the speaker alone, or by the speaker as a member of a group” (p. 54). e.g, promises, threats, refusals, pledges, invitations, swears, volunteers, offers, etc.

\section{FACE WANTS}

It is said previously that interpreting an utterance involves both a speaker and a hearer; in addition, it will also affect the participants emotionally. In politeness theory 'face' is understood as every individual's feeling of self-image; which can be damaged, maintained or enhanced through interaction with others (Thomas, 1995). According to Mey (2001), the term 'face', as an explanatory concept in human interaction, was originally introduced by Erving Goffman. In line with the above explanation, Yule (1996) also adds that "within everyday social interaction, people generally behave as if their expectations concerning their public self-image, or their face wants, will be respected” (p. 61).

Trosborg (1995) argues that people are allowed to defend their faces if threatened, and when defending their own faces they are likely to threaten other people's faces in turn. In achieving smooth and successful communication, the participants in an interaction should maintain each other's face.

There are two kinds of face wants. The first is called face threatening act and the second is face saving act. Yule (1996) mentions that "if a speaker says something that represents a threat to another individual's expectations regarding self-image, it is described as a face threatening act" (p. 61). When face is being threatened interaction, it comes under attack. Brown and Levinson (as citeed in Thomas, 1995) also implies that 'face threatening acts' happen when certain utterances are likely to damage or threaten another person's face. Yule (1996) mentions that a face saving act happens when a speaker say something to lessen the possible threat.

\section{METHODS}

In gathering and processing the data for this analysis, the writer first reads some episodes of Tintin and Asterix comic. Second, the writer 
collects, selects and classifies the data, which are in the form of sentences or phrases as the utterances of the conversations in those comic series which cause misinterpretation. Third, the writer analyzes the data by focusing on the misinterpretations which have been caused by the different interpretations of speech act labels, and by observing the effects of those misinterpretations on the participants. Finally, the writer composes a report of the research.

\section{FINDINGS AND DISCUSSION}

After doing the analysis of 'Tintin' and 'Asterix' comic series, the writer finds out that there are some events of misunderstanding which are based on the Taxonomy types involved. In this case, a speech act label of one utterance which is conveyed by a speaker is differently interpreted by a hearer.

From the thirty-two data that have been analyzed, the writer finds that most of the data show that the misunderstandings happen because the speaker and the hearer have different interpretations concerning the taxonomy classification. There are thirteen data showing the misunderstandings from Directive to Expressive types. For example, as found in the dialog below:

Tintin

: "Excuse me, if anyone finds a pipe under their seat, could they please return it to this gentleman at the end of the seminar."

Captain Haddock : "Blistering barnacles! D you find it funny to publicly humiliate me?”

The data above shows the event when Captain Haddock and Tintin attend a seminar about 'Health and Magnetism with Mystic' brought by Endaddine Akass, a famous spiritualist. In the middle of the seminar, Captain Haddock loses his pipe. At that time, he is so busy looking for his pipe that the other people present at the seminar feel annoyed owing to the fact that he asks everyone who sits near him about his lost pipe. Afterwards, Tintin tries to help Captain Haddock in finding his pipe by announcing it in front of the audience so that he will get his pipe back.

In that case, as the speaker, Tintin actually intends to perform a face saving act through the polite request (Directive) conveyed to the audience of the seminar. Nevertheless, a misunderstanding occurs in this 
conversation. As the hearer, Captain Haddock misinterprets Tintin's utterance as a face threatening act as he interprets it as a humiliation (Expressive). He feels humiliated and angry because he thinks that Tintin has embarrassed him in front of that audience of the seminar. Captain Haddock thinks that the fact about his lost pipe is not supposed to be announced in front of the seminar audience because this is not something important that everyone should know about.

In addition, there are also eleven data which show the misunderstandings from Representative to Expressive types as shown in one of the data below:

Detective Thompson: "Captain, is what Tintin says really true? He's just told us you've decided not to go. It seems you broke a mirror and afraid..."

Captain Haddock : "Afraid? Me, afraid?... Afraid of what?... afraid of whom?...

Afraid of you perhaps? Captain Haddock fears nothing! You understand? We weigh anchor at dawn tomorrow, no matter what anyone says!...”

The conversation shown above is part of the story when Tintin and Captain Haddock are going to find some treasure belonging to a pirate named Red Rackham. Red Rackham is killed long ago by Sir Francis Haddock aboard a ship called the Unicorn. In this case, Captain Haddock joins this treasure hunting owing to the fact that he is one of Sir Francis Haddock's descendants.

In the data mentioned above, at first, Captain Haddock plans to join Tintin in finding the Red Rackham's treasure by cruising on the sea. Then, he cancels the plan for the simple reason that he feels uneasy after breaking a mirror in a second hand shop which sells diving equipment. Captain Haddock is afraid that something wrong may happen on the treasure hunting; in addition, he feels that it is a bad sign.

On the day of the expedition, Detective Thompson, as the speaker, intends to perform a face saving act by asking whether Captain Haddock really cancels the plan. At that time, Detective Thompson just gives the statement (Representative) that Captain Haddock seems afraid of cruising on the sea. 
In hearing Detective Thompson's statement, a misunderstanding occurs. Captain Haddock, as the hearer, misinterprets the speaker's utterance as a face threatening act. He really feels offended because he thinks that Detective Thompson has insulted him about his fear of cruising, so that he replies Detective Thompson's utterances angrily. He misinterprets Detective Thompson's utterance as an offence (Expressive). In addition, he wants to prove that he still wants to go on finding the treasure no matter what anyone says.

There are three data showing the misunderstanding from Expressive to Directive types, and one data from Directive to Representative types. One of the examples is shown below:

Julius Pompus : "What happened, O Crismus Bonus?”

Centurion Crismus Bonus: "I tripped over my beard, idiot!"

The Gauls are famous for their magic potion made by a Druid named Getafix. This magic potion can make the Gauls have extraordinary strength so that they always win their fight with the Romans, who are always at war with the Gauls as they always want to conquer the Gauls.

In this part of the story, Crismus Bonus wants to know about the recipe of the Gauls' magic potion in order to make the Romans have the same extraordinary strength as the Gauls. Then, he orders some Roman soldiers to kidnap Getafix, the magic potion maker. Getafix is strictly kept at the Roman camp. He is also forced to make a cauldron of magic potion for the Romans. If he does not follow the order, he will be killed.

The data above shows the event when Crimus Bonus is tripped over by his own beard which grows rapidly. His beard grows very fast because of the wrong magic potion he drinks. Druid Getafix makes the wrong potion on purpose. The potion does not affect his strength, but it fastens the growth of his beard. In that panicky situation, a Roman soldier named Julius Pompus intends to show his sympathetic expression (Expressive) through a question to Crismus Bonus. As the speaker, he intends to perform a face saving act.

However, a misunderstanding appears when Crismus Bonus as the hearer, interprets the speaker's notion of face as a face threatening act. In this case, Crismus Bonus interprets Julius' utterance as only a question (Directive). He thinks this is a silly question that does not need to be answered as Julius has seen the incident himself. Therefore, he replies Julius' utterance rudely. Moreover, he is very annoyed and calls Julius 
Pompus an idiot because he thinks that Julius is supposed to know that he is tripped over by his beard.

Noxious Vapus : "Er... Caesar... it might save time to use some other shield... a nice new one. I happen to know a little armourer who..."

Julius Caesar : "Vade retro, Vapus! I shall have my triumph on that Arvernian shield and none other! And don't you try to deceive me! To deceive Caesar is to deceive the Gods, and the anger of the Gods would be terrible!”

In this story, the Romans led by Julius Caesar fight against the Avernians to conquer the Gaullish village. At that time, Julius defeats the Avernians and the whole Gaul is officially occupied. Vircingetorix, the leader of the Avernians, gives his weapons as the symbol of his defeat to the Romans by throwing it to the leg of Julius Caesar. However, at that moment, there is a Roman soldier who takes the weapons.

The data above shows the event when Noxious Vapus, a Roman soldier who is sent by Julius Caesar to visit the Avernian village. In that village, he is attacked by the Avernians. Afterwards, he goes back to Rome to report the unpleasant occasion. Suddenly, Julius Caesar remembers the weapons used as the symbol of defeat which is thrown at his feet when he defeats the Avernians a long time ago.

On hearing the report from Noxious, Julius Caesar plans to revenge the Avernians by finding the lost Vircingetorix's weapons and using them to attack the Avernians. He asks Noxious to find those weapons. Being lazy to find the same weapons, Noxious intends to make an excuse to Caesar. He suggests that Julius Caesar should use other new weapons in performing the revenge because it will waste their time only to find the lost weapons. As the speaker, he intends to perform a face saving act through his suggestion (Directive).

However, in hearing the suggestion, Julius feels that Noxious lies and makes fun of him by making such excuses. He does not believe if the weapons are missing for the simple reason that he is not that foolish to deceive. As the hearer, Julius misinterprets Noxious' utterance as a face threatening act as he considers it a lie (Representative). In addition, he insists that Noxious should find the lost weapons.

The number of speech act labels misinterpretation are summarized in Table 1. 
Table 1. The Number of Speech Act Labels Misinterpretation

\begin{tabular}{|c|c|c|}
\hline \multicolumn{2}{|c|}{ Misunderstanding of speech act labels } & \multirow{2}{*}{ Tota } \\
\hline \multicolumn{2}{|c|}{ Directive $\rightarrow$ Expressive } & \\
\hline polite request & humiliation & 1 \\
\hline Suggestion & accusation & 1 \\
\hline Suggestion & insult & 3 \\
\hline Advice & insult & 1 \\
\hline Question & order & 1 \\
\hline Mockery & question & 2 \\
\hline Warning & insult & 2 \\
\hline Order & question & 1 \\
\hline Question & accusation & 1 \\
\hline Question & insult & 1 \\
\hline Offer & humiliation & 1 \\
\hline offer & insult & 2 \\
\hline \multicolumn{3}{|c|}{ Representative $\rightarrow$ Expressive } \\
\hline Truth & mockery & 1 \\
\hline Statement & accusation & 1 \\
\hline statement & offence & 1 \\
\hline Statement & insult & 2 \\
\hline Statement & mockery & 1 \\
\hline Statement & joke & 1 \\
\hline Fact & insult & 1 \\
\hline Explanation & accusation & 1 \\
\hline Report & acusation & 1 \\
\hline Explanation & offence & 1 \\
\hline \multicolumn{3}{|c|}{ Directive $\rightarrow$ Directive } \\
\hline Question & order & 1 \\
\hline Order & question & 1 \\
\hline \multicolumn{3}{|c|}{ Expressive $\rightarrow$ Directive } \\
\hline Mockery & question & 2 \\
\hline sympathetic expression & question & 1 \\
\hline \multicolumn{3}{|c|}{ Expressive $\rightarrow$ Expressive } \\
\hline Praise & mockery & 1 \\
\hline awed expression & insult & 1 \\
\hline \multicolumn{3}{|c|}{$\begin{array}{l}\text { Directive } \rightarrow \text { Representative } \\
\end{array}$} \\
\hline Suggestion & lie & 1 \\
\hline
\end{tabular}




\section{CONCLUSION}

Based on the discussion above, it is clear that most of the misunderstandings happen because the speaker's utterances are misinterpreted as the Expressive type. In the writer's opinion, this happens due to the fact that the hearers in the conversations involve their feelings in interpreting the speaker's utterances so that they have various emotional responses such as feeling angry, accused, offended, humiliated, insulted or even happy for what the speakers have said.

Besides, the writer would also like to point out that there are some data showing misunderstandings although they are still in the same Taxonomy classification. In this case, the misunderstandings happen because both of the speaker and hearer have different interpretations of speech act labels. There are two data showing misunderstandings of this kind in the Directive type. As mentioned in the analysis, the speaker's order is interpreted as a question by the hearer, and a question is interpreted as an order. There are also two data showing this kind of misunderstanding in the Expressive type. They are the speaker's praise which is interpreted as a mockery by the hearer, and the speaker's awed expression which is interpreted as an insult.

Those misunderstandings happen because, although the Taxonomy classification is the same, each dialogue consists of different speech act labels which reveal different messages and responses.

It is common that in our daily conversation the speaker and hearer often misunderstand each other through the positive or negative impression and meaning of an utterance. Sometimes, the positive impression intended by the speaker is interpreted wrongly by the hearer. It depends on how the speaker conveys the utterance and whether the language is used in the appropriate context or not.

From the misunderstandings that have been discussed, there must be some effects on the participants in the conversations. This is illustrated as the 'notion of face'. In the twenty-nine data of misunderstandings, the effects show that the hearers interpret the speakers' face saving act as face threatening act. Meanwhile, only in the three data do the effects imply that the hearers interpret the speakers' face threatening act as face saving act.

Based on the analysis carried out, the misunderstandings in Tintin and Asterix comic series tend to perform a face threatening act because most of the hearers in the conversations feel embarrassed and threatened by the 
speakers' utterances. Most of them interpret the speaker's utterances negatively.

In these comic series, we often find the funny scenes caused by some factors. In this case, 'misunderstanding' becomes one of the influencing factors because the reader will be amusingly entertained by noticing that there is something wrong yet funny in the conversations. Those conversations usually will lead the readers to a different perception of what has been said by the speaker and what has been understood by the hearer.

Besides, there are also other elements causing the funny scenes which support the misunderstanding events both in Tintin and Asterix comic series. In these comic series, the misunderstanding is strongly supported by the stereotypical and unique characters appearing in the story. For example, the misunderstandings often happen through the characterization of Captain Haddock, who is almost always bad-tempered and stubborn, and the twin detectives Thomson and Thompson, who are always clumsy and careless. In Asterix, the character of Obelix is described as a rather stupid, sensitive and clumsy person, Asterix, is described as a smart and serious character. Usually, the misunderstandings happen between the opposing characters. Every character in these comic series has his or her own specialty which is very dominant so he or she is often involved in the events of misunderstanding.

As a closing remark, the writer would like to say that some comic series, especially Tintin and Asterix are not only entertaining us through their comedy situation, but they also have many elements which are worth being analyzed through linguistic area.

\section{REFERENCES}

Al-Marrani, Y. M. A. (2010). Polite request strategies by male speakers of Yemeni Arabic in male-male interaction and male-female interaction. The International Journal of Language Society and Culture, 63. Retrieved May 2, 2011, from http://www.pdfssearch.com/Polite-Request-Strategies-byMale-Speakers-of-Yemeni-Arabic-in-...

Brown, P., \& Levinson, S. (1987). Politeness: Some universals in language. Cambridge University Press.

Grundy, P. (2000). Doing pragmatics. London: Arnold. 
Kusumarasdyati. (2005). Verbal offer used by snack vendors in Malang. $k @ t a$, 7(1), 14.

Leech, G. (1991). Principles of pragmatics. London and New York: Longman.

Levinson, S. (1995). Pragmatics. Cambridge University Press.

Mey, J. L. (2001). Pragmatics: An introduction. United States of America and United Kingdom: Blackwell Publishing.

Schiffrin, D. (1994). Approaches to discourse. Blackwell Publishers.

Sukarno. (2010). The reflection of the Javanese cultural concepts in the politeness of Javanese. $k @ t a, 12(1), 59$.

Thomas, J. (1995). Meaning in interaction. London and New York: Longman.

Trosborg, A. (1995). Interlanguage pragmatics: Requests, complaints and apologies. Berlin and New York: Mouton de Gruyter.

Tupan, A. H., \& Natalia, H. (2008). The multiple violations of conversational maxims in lying done by the characters in some episodes of Desperate Housewives. k@ta, 10,(1), 63.

Yule, G. (1996). Pragmatics. Oxford University Press.

\section{APPENDIX}

\section{Dialogue of Misunderstanding}

Tintin Comic Series

1. Tintin : "Excuse me, if anyone finds a pipe under their seat, could they please return it to this gentleman at the end of the seminar."

Captain Haddock : "Blistering barnacles! D you find it funny to publicly humiliate me?”

2. Tintin : "And its hairy legs!... it makes me shiver to think of them!"

Professor Decimus : : "Its legs?... What legs?"

Tintin : "What legs?... Why, belonging to that gigantic spider..."

Professor Decimus : "Spider?... is this your idea of a joke, young man?" 
3. Tintin

Professor Decimus :

4. Philippulus

Tintin

Philippulus
: "But... it's impossible... you... I mean... Perhaps you made a mistake in your calculations."

: "Made a mistake? Us? You presume to...? Very well! Check them!”

: "I am Philippulus the prophet! I proclaim the day of terror!... the end of the world is high! All men will perish!... and the survivors will die of hunger and cold!... There will be pestilence, and famine, and measles!”

: “Look here Mr. Prophet, why don't you go home? You'd better off in bed!..."

: "You hear that? He dares to set himself up against Philippulus the prophet... an advocate of the devil! ... a son of satan!... a tool of beelzebub! Get back to satan, your master!”

5. Captain Haddock : "Er... it might be as well, for a clear conscience, to let a doctor have a look at her."

Mike

: “A doctor! I suppose you think we have money to pay for a doctor!"

6. Captain Haddock : "Well, goodbye, and take care of that little cherub. But if you take my advice, you'll camp somewhere else, and not on this rubbish-dump... in the first place, it's unhealthy..."

Mike

: 'D'you think we're here because we like it? D' you imagine we enjoy living surrounded by filth?”

7. Irma

: "Excuse me, madame, have you seen my embroidery scissors... you know, the little gold ones..."

Lady Castafiore : "Why should I have seen them, girl? It's not my job to look after your things.”

8. Lady Castafiore : "Have you seen the marvelous article about me in 'Paris- Flash'”

Captain Haddock : "Yes, I have seen it, madam!... you call it marvelous?... Announcing our marriage!...”

Lady Castafiore : “Oh, yes, priceless, isn’t it?”

9. Tintin

: "Here, your hats!... and mind the cables!" 
Detective Thomson : “Thank you, we can manage... we've told you before: we're not children!”

10. Professor Calculus : “Ah, dear lady. It’s quite extraordinary; I just found this magazine on the floor... and guess whose charming likeness adorns the cover... look!”

Lady Castafiore : "I know, Professor Candyfloss! I know!... and kindly refrain from calling it a likeness!!”

11. Detective Thomson : "In a nutshell... if the theft was committed by someone in the house, then there are only six suspects: Irma, Wagner, Nestor, Tintin, and of course you yourself, captain."

Captain Haddock “Are you suggesting...!?”

12. Detective Thompson: "Captain, is what Tintin says really true? He's just told us you've decided not to go. It seems you broke a mirror and afraid...”

Captain Haddock : "Afraid? Me, afraid?... Afraid of what?... afraid of whom?... Afraid of you perhaps? Captain Haddock fears nothing! You understand? We weigh anchor at dawn tomorrow, no matter what anyone says!...”

13. Detective Thomson : “Oh?... but you are sure we're near it?”

Captain Haddock : "Positive! I plotted the position yesterday at noon."

Detective Thomson : "Yes, I see. But... er... supposing you made a mistake in your calculations..."

14. Captain Haddock “Oh, so I made a mistake in my calculations, did I?... All right: they're on my table. Go and check them!... Yes, you!

Now! Go on! Check them!”

Captain Haddock : "Thundering typhoons! What are you two doing there, instead of pumping?”

Detective Thompson: 'Us? We' re resting... it’s tiring work, you know."

Captain Haddock : "You infernal impersonations of Abdominable Snowmen! Pump for your lives!... Faster!”

15. Professor Calculus : "I have been very ably supported by my engineer, Frank Wolff. You met him earlier. And I'm just 
completing plans For a nuclear-powered rocket in which I propose to land on the moon...”

Captain Haddock "Ha! Ha! Ha! Ha!... the moon!... Old Calculus on the moon! Ha! ha! Ha! The things you think of!... the moon!... that's a good one!... ha! Ha! Ha!... the moon!... as easy as pie!... a man on the moon!... you'll be the man in the moon!... ha!

Ha! Ha! Oh! Ho! Ho!... I haven’t laughed so much for years!... on the moon!... and he's quite serious about it!... you old humbug, Calculus! Here’s to you!... ha! Ha! Ha!

Passengers for the moon, all aboard the bus!... Sorry, the rocket!... you are taking passengers, I hope?”

Professor Calculus : "Of course!... why else do you think I asked you to join me?..."

16. Detective Thompson: "All the same, be careful."

Detective Thomson : "I'm not a child, am I?"

17. Captain Haddock : "Have you seen my pipe?”

Mr. Baxter

: "Your pipe? What would I want with your pipe?... I’m sorry but I haven’t time to worry about your pipe now!”

18. Professor Calculus : “My poor friend! Didn't you notice the door was rather low?"

Captain Haddock : "D’you think I did it on purpose?... I suppose you think my favorite pastime is cracking my head against doors? Well, I've had enough of being a playmate for neurotic mice!"

19. Detective Thomson : "Well, you're very wise not to go on such a wild goose chase!... It's a ridiculous idea!... Besides, at your age it would be sheer madness!"

Captain Haddock : "What? At my age?!... I suppose you take me for a rusty old tub, ready for the scrapheap?... you'll see how old I am, you Bashibazouks!... I'm going, d'you hear?... and I'll send you a postcard from the moon!”

20. Captain Haddock : "Thundering typhoons! Why does this cork have to be so stubborn?”

Frank Wolff : : "Would you like me to try, captain?" 
Captain Haddock : "Are you proposing to teach me how to open a bottle of champagne?”

Frank Wolff : "But...”

21. Captain Haddock : “Good heavens, what a leap!”

Tintin : "Ha! Ha! Ha! You see, captain! On the Moon, gravity is actually six times less than on the earth."

Captain Haddock "And I knew that all the time, thundering typhoons!... but I'd completely forgotten.”

22. Detective Thomson : "Now don’t try any funny business with us, my friend... come on, what's your name?”

A man $\quad$ : “I... let's see... it's really very odd, but I... I can't remember!...”

Detective Thomson : "For the last time, my man, don't try any funny business with us... what's your name?”

Asterix Comic Series

23. Julius Pompus : "What happened, O Crismus Bonus?"

Centurion Crismus Bonus: "I tripped over my beard, idiot!”

24. Huevos Y Bacon : "What a big nose you have!”

Vitalstatistix : "Humph! Take him away! We'll go on this conversation after my afternoon nap!”

25. Asterix

Pub owner

26. Caius Fatuous

Obelix

Caius Fatuous

27. Psychoanaltyx Asterix
: “That's wine all right”

: “Goodness gracious! Of course it's wine! It's perfectly safe todrink it!”

: “Just taste these pasties! They're a new recipe - they cost a fortune! Nightingales' tongues imported from the north of Gaul, sturgeon's eggs from the farthest barbarian lands, cockroaches' from Mongolia... well, what do you think of them?"

: "Salty"

: "Salty! huh! These barbarians don't appreciate good food! Bring me the giblet jam!”

: "What happened to him? Some sort of a shock?”

: "Yes, it was a menhir got him down" 
Obelix : 'I don't think it was that at all. You always make out it was my fault. You're not going to tell me that little tap with a...”

28. Fulliautomatix $\quad$ : "The Romans have got the magic potion! We saw them!"

Asterix $\quad$ : "That's ridiculous! How could they have managed to find out the secret?"

Fulliautomatix : "We've been seeing a lot of Romans around the village lately."

Asterix : "Are you accusing me of giving the Romans secret of the magic potion?”

29. Impedimenta $\quad$ : “Oh, Tapioca, how wonderful!”

Homeophatix : : "Of course, it must be a bit of a change from the stuff you get to eat at home!"

Vitalstatistix : "And what's wrong with what we get to eat at home?”

30. Julius Caesar : 'Well, my dear Vapus, you’ll just have to go back to Gaul and look for the shield Vercingetorix threw at my feet”

Noxious Vapus $\quad$ : "Er... Caesar... it might save time to use some other shield... a nice new one. I happen to know a little armourer who..."

Julius Caesar $\quad$ : "Vade retro, Vapus! I shall have my triumph on that Arvernian shield and none other! And don't you try to deceive me! To deceive Caesar is to deceive the Gods, and the anger of the Gods would be terrible!”

31. Geriartrix $\quad$ : 'You're buying menhirs here, right?"

Caius Preposterus : "Yes, indeed! Let us help you unload them, venerable old gentleman"

Geriartrix : :Old? I'll show you if I'm old, Roman!”

32. Asterix : "We can move freely without the cart... but you'd better give me the bag. The poor horse can't carry its weight as well as yours"

Obelix : "My weight? What about my weight?" 